\title{
Learning from the Malaysian Experience: Overcoming the Regulatory Challenges in the Nascent Takaful Practice Innigeria
}

\author{
Muhammad Musa Saleh ${ }^{1,2}$, Sujata a/p Balan ${ }^{1} \&$ MD Khalil Bin Ruslan ${ }^{1}$ \\ ${ }^{1}$ Faculty of Law, University of Malaya, Kuala Lumpur, Malaysia \\ ${ }^{2}$ Department of Private Law, Faculty of Law, University of Maiduguri, Maiduguri, Borno State, Nigeria \\ Correspondence: Muhammad Musa Saleh, Faculty of Law, University of Malaya, Kuala Lumpur, Malaysia. \\ E-mail:mmdeji@yahoo.com
}

Received: March 28, $2016 \quad$ Accepted: May 10, $2016 \quad$ Online Published: August 30, 2016
doi:10.5539/jpl.v9n7p142
URL: http://dx.doi.org/10.5539/jpl.v9n7p142

\begin{abstract}
The Islamic insurance (Takaful) introduced in March, 2013, was specifically meant to bridge the endemic insurance gap in Nigeria by engendering deepening insurance penetration and financial inclusion of the hitherto underserved and uninsured huge Muslim clientele. However, the Takaful Operational Guidelines and a host of other enabling insurance instruments are caught up in a web of regulatory conflict and ambiguity. The legal effect of this is a huge regulatory vacuum that is bound to impact negatively on capital investment climate, breed mistrust and uncertainty and discourage participation in the nascent Takaful industry. Nigeria would need to draw from the vast experiences of Malaysia in order to overcome these challenges. Nigeria and Malaysia are both former British colonies with diverse ethnic and socio-cultural backgrounds. They both practice divergent legal systems in a secular setting. Both have sizeable numbers of Muslim population. While Malaysia is considered the hub of Takaful practice in the world, Nigeria is just an emerging market in the now trending Islamic financial revolution. This paper examines the enormous general and regulatory challenges the nascent Nigerian Takaful practice will encounter in its quest to attain sustainability and vibrancy. The methodology of the study is both doctrinal and qualitative whilst employing non-random sampling technique. The study employs both primary and secondary sources of information and interviews where appropriate. The study finds the need for a review and harmonization of all the enabling insurance instruments in Nigeria, transforming the current business models and improving practices in the insurance sector to enhance the application of Takaful. The study recommends the enactment of a Takaful Act like that of Malaysia.
\end{abstract}

Keywords: Takaful, Shariah, regulatory, Malaysia, Nigeria

\section{Introduction}

The Nigerian insurance industry has a history of niggling endemic insurance gap brought about by the prevalence of several factors, especially the very nature and practice of conventional insurance itself in a predominantly Muslim environment. In general, there is limited public awareness of insurance in Nigeria, and distrust by those who are aware of it, particularly in urban areas. The Islamic insurance (Takaful) Operational Guidelines introduced in March, $2013^{1}$, as an alternative to conventional insurance, were meant to bridge this endemic gap by engendering deepening insurance penetration and financial exclusion of the hitherto underserved and uninsured huge Muslim clientele ${ }^{2}$. However, the Takaful operational guidelines and a host of other enabling insurance instruments are caught up in a web of regulatory conflict and ambiguity. The legal effect of this is a huge regulatory vacuum that is bound to impact negatively on capital investment in Takaful and discourage

\footnotetext{
${ }^{1}$ To create an enabling environment for registration and smooth take-off of full-fledged Takaful insurance application in Nigeria, the National Insurance Commission (NAICOM) exercised its powers under Section 100 of the Insurance Act, 2003 and issued guidelines for Takaful insurance which have the objectives of:-

(a) providing minimum standards for the operation of Takaful insurance in Nigeria, (b), ensuring consumer protection in relation to Takaful insurance products, (c), setting up general requirements for Takaful insurance, (d) establishing duties and responsibilities of Takaful insurance operators and other insurance institutions in the market and (d) setting conditions for the entry and exit of operators from Takaful business.

${ }^{2}$ Growing international experience increasingly shows that Takaful is a viable business that can help in closing the gap between the minority who has access to formal risk mitigating tools, and the large majority who is financially excluded.
} 
active participation by the populace. This poses a serious threat to the much desired financial inclusion and deepening insurance drive of the National Insurance Commission (NAICOM), the chief regulator of the Nigerian insurance industry, and other stakeholders. The quest to attain expected heights and contribute more significantly to the nation's gross domestic product will remain a mirage if this absence of synergy between the enabling insurance regulatory instruments is allowed to fester. Overcoming these challenges through the harmonization of these instruments in a wholesome Takaful Act as found in Malaysia, is bound to fill the legal void, establish regulatory certainty and build trust leading to the active participation of the populace and stakeholders alike in Takaful insurance.

Malaysia as the number one Takaful nation in the world has experienced the type of teething problems Nigeria is facing today in the quest for the realization of a vibrant Takaful industry. A lot of literature and empirical evidence has shown that countries would have a more stable long-run growth if supported by a better developed financial system. One of the financial instruments that support economic growth is insurance, a tool that is used to mitigate risk. The achievements of Malaysia in pioneering the world Takaful revolution has left almost all the countries of the world in looking up to it for guidance. Malaysia controls about $30 \%$ of the world's Takaful assets of the Takaful industry ${ }^{3}$.

Malaysia has begun to play its leading role by organising and conducting special educational programmes for Takaful personnel in the Asean region ${ }^{4}$ as well as others through the formation of Bank Islam Research and Training Institute (BIRT). Malaysia has helped other parties outside the Asean region to introduce and promote Takaful in their respective countries. For this purpose, Takaful Malaysia has established joint venture programmes in Sri Lanka, Saudi Arabia and also provided technical assistance for Takaful operators in Australia. Request for similar assistance has been sought from Lebanon, Bangladesh and Algeria among a host of numerous countries ${ }^{5}$. Nigeria cannot afford to be an exception.

This paper thus examines the basic regulatory discrepancies inherent in the Insurance Act, 2003, the recently introduced Takaful Operational Guidelines, 2013 and a host of other enabling insurance instruments, and the experience of Malaysia in overcoming such challenges. Recommendation is made for statutory underpinning.

The authors' objective is to show that insurance regulatory framework in Nigeria, particularly the Insurance Act and Takaful Guidelines are enmeshed in a web of regulatory conflicts and ambiguities. The absence of regulatory clarity is bound to be detrimental to the success of Takaful and Nigeria needs to borrow from the advances of Malaysia in solving the problem.

This research is doctrinal, qualitative, and based purely on library research covering books, statutes, law reports, and internet sources from renowned databases and websites. To realize the set objectives, the authors will highlight key sections of the Insurance Act, 2003, the Takaful Operational Guidelines, 2013 the Companies and Allied Matters Act, 1990 and the Investment and Securities Act, 2007. All these will be assessed in order to determine the extent of lack of synergy in the enabling insurance instruments and how it will impact negatively on the nascent Takaful industry if not remedied.

The scope of this paper, however, is limited to the regulatory challenges and does not cover all the challenges Takaful application in Nigeria is bound to face. This is an area for further study. The relevance of this paper and the choice of jurisdictions are justified thus:

1) There has not been any study on the regulatory challenges of Takaful in Nigeria because Takaful guidelines have just been released recently. To the best knowledge of the authors, this is the first time a study of this nature is being carried out extensively. Interviews with some staff of National Insurance Commission of Nigeria, NAICOM, which is the chief insurance regulator, notable insurance companies, lawyers, academics and ordinary citizens all point to the fact that this area of research is quite new.

2) Nigeria and Malaysia are former British colonies. Both possess plural legal systems and written constitutions with similar framework. They both have large Muslim populations. Both countries are multi-lingual,

\footnotetext{
${ }^{3}$ According to Kamsani Tati of Tokyo Marine Nichidon ReTakaful. See Jordan Times, 16 January, 2015.

${ }^{4}$ The Asean ReTakaful International Labuan Ltd (ARILL) was established by the Asean Takaful Group (ATG) members in 1997, which aims to enhance cooperation, particularly through training, to build a strong reTakaful capacity as well as to facilitate reTakaful exchanges among members. The D-8 Summit held in 1999, agreed to introduce, promote and develop Takaful in all D-8 countries and endorsed a proposal to enhance the capacity of an existing reTakaful company to meet the needs of D-8 member countries. At this Summit, Malaysia was entrusted to develop Takaful and reTakaful business in the member countries. See Ahmed, S., (2006), Islmaci Banking, Finance and Insurance, A Global Overview, A. S. Noordeen Publishers, Kuala Lumpur, p. 517.

${ }_{5}^{5}$ Ahmed, S., (2006), Islamic Banking, Finance and Insurance, A Global Overview, A. S. Noordeen Publishers, Kuala Lumpur, p. 517.
} 
multi-cultural and multi-religious with similar urban rich/rural poor socio-economic divides. What rightly suits Malaysia in Takaful application will equally be beneficial to Nigeria because of the shared similarities.

3) Nigeria is short of technical expertise in Shariah and Takaful matters to address the regulatory issues on its own hence the need to look up to big brother Malaysia for the requisite assistance.

\section{Overview of Insurance Practice in Nigeria}

The Nigerian insurance industry can be broadly divided into four categories: (a) those regulated by the National Insurance Commission (NAICOM), forming the largest group; (b) health insurance, which is regulated by the National Health Insurance Scheme (NHIS); (c) agriculture insurance, provided almost exclusively by the Nigerian Agricultural Insurance Corporation (NAIC) ${ }^{6}$; and the cooperative sector, which offers insurance to their members ${ }^{7}$.

Historically, rudimentary form of insurance practice has been in existence long before the advent of English Common law in Nigeria which was occasioned by colonial conquest ${ }^{8}$. Age grades and tribal associations have been practising some form of mutual assistance resembling a life insurance contract ${ }^{9}$.

There are many other informal and community-based schemes that are employed to manage risks. These are mainly in the form of savings, reciprocal borrowing from friends and family, high interest loans from a variety of sources and by selling assets. Savings clubs or savings at cooperatives, friendly societies and Asusus are commonly used in Nigeria. These local financial institutions are readily accessible, culturally accepted and widely used ${ }^{10}$.

The Nigerian legal system recognises three forms of insurance namely; conventional insurance ${ }^{11}$, customary insurance and Islamic insurance, albeit by inference. Conventional insurance has been the dominant insurance practice in Nigeria. This has been so because it is government entrenched as reflected in the various enabling laws of insurance practice in Nigeria. The Nigerian government has even gone farther in making some aspects of insurance compulsory like the third party motor vehicle insurance contract. Conventional insurance is the most popular form of insurance contract in Nigeria by virtue of lingering colonial heritage and active government patronage. This system of insurance has succeeded in creating an endemic gap in the Nigerian insurance industry due to low-level patronage and financial exclusion of most of the populace. Most Nigerians do not understand it and abhor it ${ }^{12}$; hence they do not buy into it except the compulsory third party/motor vehicle insurance ${ }^{13}$.

The average Nigerian suffers from lack of awareness about insurance process. He does not understand how he pays premium for an insured risk yet cannot recover his money when the event does not occur. Again many insurance companies have not been transparent in their dealings. There is a long standing mutual suspicion between the parties right from the early days in the history of conventional insurance practice in Nigeria. Many innocent insured customers were fleeced by rogue insurers leaving scars of the attendant damage in the psyche of

\footnotetext{
${ }^{6}$ NAIC provides subsidized and commercial agricultural insurance. NAICOM regulates only the commercial portfolio. See Access to Insurance Initiative, (2013), (Denis Dias et al eds.) Towards Inclusive Insurance in Nigeria: An Analysis of the Market and Regulations, Eschborn, p. 26.

${ }^{7}$ Ibid.

${ }^{8}$ Okany, M. C., (1992), Nigerian Commercial Law, Africana First Publishers Plc, p. 811.

${ }^{9}$ Okany, M. C., (1992), Nigerian Commercial Law, Africana First Publishers Plc, p. 811. Here, the members of the group raise funds through levies and donations from which a handsome amount will be presented to the next of kin of a deceased member on the occasion of the demise of such a member. See also Achike, O., (1985) Commercial Law in Nigeria, University Press, p. 316.

${ }^{10}$ Access to Insurance Initiative, (Denis Dias et al, eds), (2013), Towards Inclusive Insurance in Nigeria: An Analysis of the Market and Regulations, Eschborn, p. 45.

${ }^{11}$ The concept of conventional insurance is founded upon the law of contract. Like in any other case, therefore, all rules of contract apply to an insurance contract. Accordingly, for example, parties to an insurance contract will have the right to determine their obligations under the contract, and the court will refrain from interfering with the rights of the parties except where the terms of such contract are manifestly unreasonable to the detriment of one of the parties or against the public interest. See Achike, O., op cit, p. 313.

${ }^{12}$ Most Nigerians hold conventional insurance with contempt. They see insurers as eager to collect premium from the insured at the beginning of the contract but unwilling to settle genuine claims when they arise. Nigerians have therefore chosen to avoid insurance except perhaps for the few insurance products that have been made compulsory. Even in the case of compulsory insurances, many have found means of escaping the eyes of the law enforcement agents through patronizing fake insurance agents.

${ }^{13}$ Demonstrating a surprising apathy, the bulk of the insurance industry is accommodated in its focus on corporate and compulsory contracts. It offers very little to retail customers beyond compulsory insurance. Moreover, its previous experience with voluntary retail products has been marked by practices such as not paying claims, which have tainted the industry's reputation, resulting in low levels of public confidence and the perception that insurance does not offer value to the insured. The strong emphasis in compulsory insurance at both the policy and industry levels may worsen this public perception. See Access to Insurance Initiative, (2013), Towards Inclusive Insurance in Nigeria: An Analysis of the Market and Regulations, Eschborn, p. 8.
} 
numerous citizens.

The Nigerian insurance industry is today ranked $65^{\text {th }}$ globally in terms of size and $6^{\text {th }}$ out of the 8 largest industries in Africa. The sector has contributed less than one per cent to the Gross Domestic Product (GDP) due to systemic failures of regulation and supervision. The industry grows at an average rate of $23.0 \%$ and $20.7 \%$ for Life and Non-Life businesses respectively ${ }^{14}$.

Though, the insurance industry in Nigeria has over the years recorded some measure of growth, with gross premium increasing from N55.9 billion in 2003 to N164.5 billion in 2015, this represents an insurance penetration of only 0.6 per cent in the country. According to Sigma Re report of 2014 on the Nigerian market, Life Business posted USD193 million while Non-Life accounts for the balance of USD1.044 billion. With a population of 151.5 million, insurance density records USD 8.2 for both Life and Non-Life Businesses. This abysmal scorecard reflects a market suffering slow growth syndrome. In a slow growth industry, such as the Nigerian insurance underwriting industry, it is difficult to achieve significant improvements without taking market share from competitors ${ }^{15}$.

The apparent dismal performance of conventional insurance practice occasioned by low penetration ${ }^{16}$ and financial exclusion of the majority of the populace, forced the insurance regulator, NAICOM and some other notable stakeholders to search for alternative means of making the insurance industry vibrant so that it could play its expected role in contributing positively to the Nigerian economy. Islamic insurance or Takaful became a viable option and a potentially effective means of bridging the endemic insurance gap because of the hugely underserved and financially excluded Muslim clientele ${ }^{17}$.

Islamic finance has made remarkable inroads in world financial circles and Islamic insurance (Takaful) which is a component part of Islamic finance has found unprecedented acceptance in numerous economies of the world.

The concept of insurance evolved from mutual help in times of need and distress, rather than a business proposition for profit as practised today. In conventional insurance, the relationship between the insurer and the insured is that of buyer and seller. This is not the case with Islamic insurance (Takaful). Takaful promotes shared responsibilities, solidarity, mutual assistance and cooperation to protect participants (policyholders) against risks and misfortune in accordance with the policy. Hence profit is not the main objective of Takaful ${ }^{18}$.

Islamic insurance (Takaful) is the name given to the practice of insurance under the principles of Islamic finance. Technically, the concept of Takaful in the area of insurance means mutual assurance or guarantee amongst the members of a group between each other. It is basically the pooling of resources to help those who are in need. It is also seen as a mutual agreement between two parties for a mutual cooperation in protecting one's life or property from any unprotectable and unavoidable risk, danger or tragedy ${ }^{19}$.

In Nigeria, there has been a low level of Takaful activities in the insurance industry before the advent of the new Takaful Operational Guidelines. African Alliance Insurance Company Limited, being the oldest and strongest specialist in life assurance and pension, blazed the trail in introducing Islamic finance (Takaful) into the market in 2003. Since then other two conventional insurance companies have joined the fray. These are Niger Insurance Plc and Cornerstone Insurance Plc. As a composite insurance company, Niger Insurance transacts all classes of

\footnotetext{
${ }^{14}$ Yusuf, T.O., (2012), Prospects of Takaful's (Islamic Insurance) Contributions to the Nigerian Economy, Journal of Finance and Investment Analysis, Vol. 1, No. 3, Science Press, p. 221.

15 Yusuf, T.O., op cit, p. 221.

${ }^{16}$ EFInA survey states that penetration of insurance in Nigeria is at a dismal $1 \%$ of the adult population. Insurance sales revenues make up only $0.72 \%$ of Nigeria's GDP. It is estimated that only $1 \%$ of the adult population which is about 800,000 people have insurance. Out of these, $58.8 \%$ ( 0.47 million) have compulsory motor insurance (some of which are fake) and $21.6 \%$ ( 0.173 million) have life insurance.

${ }^{17}$ Vision 2020, (an ambitious All-encompassing Federal Government of Nigeria Plan for Rapid Development), describes the Nigerian insurance sector as a "grossly untapped opportunity". With approximately $70 \%$ of the 150 million strong population living below the poverty line, over half of the population living in rural areas, $52.5 \%$ of adults being completely excluded from the financial services, a growing economy amidst higher inflation, social unrest, poor basic infrastructure, and concerns with corruption, Nigeria offers great opportunities and challenges for any type of business.

The report further adds that it is not different for the insurance sector: only about $1 \%$ of the adult population is covered by insurance today, clearly showing the huge potential lying ahead of the industry. There is wide acknowledgement by the industry and other stakeholders of a largely unexplored world out there, since the Nigerian uninsured faces risks and needs the means to mitigate them better than what they can do with the informal mechanisms currently used The potential market for Takaful could be very attractive for providers, given Nigeria's young and large population that commands a Muslim majority.

${ }^{18}$ Solomon, F.O., (2014), Takaful (Islamic Insurance) Practices: Challenges and Prospects in Nigeria, Journal of Insurance Law and Practice, Vol. 4, No. 2, p. 12.

19 Ahmed, S., op cit, p. 512.
} 
insurance business and offers a wide range of innovative products and customer oriented services to its growing clientele. In addition, they support their products with one of the most efficient and constantly improving claims settlement procedures in the insurance market. Cornerstone Plc established Halal Takaful Nigeria to cater for the Muslim population. Of all the three existing Takaful underwriting companies that offer window services, only Cornerstone offers a separate Takaful office being run by one of its subsidiaries - Halal Takaful Nigeria - where assets of Takaful are not merged with conventional insurance funds ${ }^{20}$.

\section{Islamic Insurance (Takaful)}

Islamic insurance or Takaful in Arabic means joint guarantee ${ }^{21}$. The legal basis of Takaful can be found under the Shariah which is a body of rules and rulings in accordance with Islamic injunctions. Shariah is based on two primary sources namely the Noble Qur'an and the Sunnah or Hadiths (sayings of the Noble Prophet pbuh). Apart from these primary sources, there are other secondary sources of Ijma and Qiyas or the process of comparison or making analogical deductions from existing rulings to be applied to new situations of similar nature ${ }^{22}$.

As the objective of Islam is the fulfilment of life and its conveniences within the precincts of Shariah, Islam upholds trade and mutual assistance and at the same time prohibits wastage and vanity that occasion losses in trade often resulting in untold hardship and needless suffering. Takaful claims are aimed at alleviating such suffering ${ }^{23}$.

Under the Sunnah of the Noble Prophet pbuh, numerous Hadiths clearly point to the concept of Takaful in the daily affairs of Muslims. In spite of the belief in Al Qadr (predestination) in Islam, Shariah enjoins believers to make provisions in their lifetime to lighten the burden on their families in the event of death ${ }^{24}$.

The elements of insurance are enshrined in a Hadith narrated by Anas Ibn Malik where the Noble Prophet pbuh told a Bedouin Arab who left his camel untied trusting it to the Will of Allaah The Most High: hobble the camel first and then leave it to Allaah The Most High ${ }^{25}$.

Instances of Takaful abound in the practice of Arabs as exemplified by the custom of al-aqillah which was a mutual agreement among tribes for the paternal relatives of a person charged with a case of murder to make contributions for the purpose of paying blood money to the victim's relatives. This practice of pooling contributions to assist others in need encapsulates the very idea of insurance. The tradition gained acceptance with the advent of Islam. Many of the customs from the pre-Islamic period of Jahiliyya (period of ignorance) were declared "Islamic" by the Noble Prophet pbuh when he pbuh said "the virtues of the Jahiliyya are acted upon in Islam".

Given the Qur'anic command to assist one another and the words of Prophet Muhammad pbuh regarding mutual assistance, Takaful may be understood as imperative upon Muslim believers: ' ...... system based on solidarity, peace of mind and mutual protection which provides mutual financial and other forms of aid to members (of the group) in case of specific need, whereby members mutually agree to contribute monies to support this common goal" 26 .

Mutual assistance among members of a tribe was not originally a commercial transaction and contained no profit or gain at the expense of others. Rather, it evolved as a social institution to mitigate the burden of an individual by dividing it among his fellow members (group) or tribe. In contrast, most modern insurances (even mutual stock insurance entities, but not mutual associations) are capitalist-based commercial enterprise, where losses are projected in advance and funds (premiums) allocated to risks to cover them. Premiums are paid in line with such

\footnotetext{
${ }^{20}$ Yusuf, T. O., (2012), Prospects of Takaful's (Islamic Insurance) Contributions to the Nigerian Economy, Journal of Finance and Investment Analysis. Vol.1, No. 3, Science Press Ltd, p. 226.

${ }^{21}$ Ibid.

${ }^{22}$ The word Takaful does not appear expressly in the Noble Qur'an. It is derived from the word Ta'awun, or mutual assistance which connotes the same meaning. See the second verse of Surah al Maidah in the Noble Qur'an (Chapter 5 v 2) which exhorts the individual to assist others. The word Ta'awun in the verse is the underlying concept of insurance practice which means to aid, to help or to assist through mutual cooperation.

${ }^{23}$ In Suratul Al Nisa', Chapter 4 v 29 of the Noble Qur'an, Allaah SWT admonished believers on trade and mutual goodwill thus "..... you who believe, eat not up your property among yourselves and vanities; but let there be amongst you traffic and trade by mutual goodwill",

${ }^{24}$ The Prophet pbuh said, "verily it is better to leave your off-springs wealthy than to leave them poor, asking others help". See Sahih Bukhari Kitab Al-Fara'id. Again, he pbuh said, "whosoever removes a worldly grief from a believer, Allaah SWT will remove from him one of the grieves of The Day of Judgement.

${ }^{25}$ See Tirmidhi and Ibn Majah who reported this.

${ }^{26}$ Fisher, O. and Taylor, D.Y., (2000), Prospects for Evolution of Takaful in the $21^{\text {st }}$ Century, Havard University, USA, p. 12.
} 
projections of risk $^{27}$.

In short, the former practice involves compensation for actual losses upon occurrence by dividing them among the group, whereas, the latter involves the transfer of losses in advance based upon past experiences. This transfer is often from policyholders (the group) to shareholders (owners of the insurance company) and thus voids the age-old principle of mutual assistance ${ }^{28}$.

In the $19^{\text {th }}$ century, a Hanafi scholar, Ibn Abidin, discussed the idea of insurance and its legal basis and successfully introduced the insurance concept as a legal institution where the practice of Takaful is based on the public interest. In the $20^{\text {th }}$ century, Muhammad Abduh issued a fatwa (legal ruling) in 1900-1901 legalizing life insurance as in line with the teaching of Shariah. He was also of the view that the relationship between the insured and the insurance group is of a Mudharabah contract. This is because the insurance operators assume the role of the Mudharib while the insured is known as the rabbul-mal. This can be observed when the Takaful operator assumes the role of entrepreneur and invests the pool of funds and specifies how the expected profit generated is to be shared among the insured. Thus, the mutual help among the insured is observed through the concept of Tabarru ${ }^{29}$.

Other sources of Shariah presuppose those medium of regulating issues of the law outside of the Noble Qur'an and the Prophetic Sunnah of Prophet Muhammad pbuh. The Ijma or consensus of the Muslim jurists in a particular matter in Islamic jurisprudence has a binding legal effect. The greater majority of renowned Islamic scholars are unanimous in their views

That conventional insurance practice is unlawful as it stands due to the presence of elements of interest, gambling and uncertainty. This means there is no ambiguity whatsoever concerning its prohibition in light of the principles of Shariah. Takaful, based on the concept of shared responsibilities was held to be halal. In contrast, on the issue of conventional insurance, Shariah prohibits exploitation and risky investments and therefore the majority of the jurists upheld its illegality as a result of Gharar (uncertainty) and speculative nature embedded in $\mathrm{it}^{30}$. Most scholars are unanimous in their analogical deductions that Takaful is perfectly legal and is here to play a very important role in the emerging global economic order.

\subsection{Fundamentals of Takaful}

Takaful insurance is not only subject to general principles of law of contract but has certain legal principles that are peculiar to the system. Takaful contract incorporates some principles of conventional insurance on the concept of fairness in dealings as expounded by Shariah. The legality of Takaful contract is subject to the existence of operators established in accordance with the following Shariah requirements and other legal framework; $;^{31}$

a) Niyyah or utmost sincerity of intention to engage in and adhere to the rules of Takaful;

b) Integration of Shariah conditions namely: risk protection under Ta'awun principle, coincidence of ownership, participation in management by policyholders, avoidance of Riba and prohibited investments, and inclusion of Mudharabah or Wakalah principles for Takaful management.

c) Presence of moral values and ethics. The business must be conducted purely in accordance with utmost good faith, honesty, full disclosure, truthfulness, and fairness in dealings.

d) No unlawful elements that contravene Shariah and strict adherence to Islamic rules for commercial contract, namely;

- Parties must have legal capacity (i.e. 18 years and above and mentally fit);

- Insurable interest

- Principles of indemnity

- Payment of contribution

- Mutual consent

- Specific period of policy and underlying agreement

\footnotetext{
${ }^{27}$ Rodziah, A. and Zairol, A.A., op cit, p. 4.

${ }^{28} \mathrm{Ibid}, \mathrm{p} .5$.

${ }^{29}$ Rusni, H., (2011), Islamic Banking and Takaful, Pearson Custom Publishing, p. 186.

${ }^{30} \mathrm{Ibid}$.

${ }^{31}$ Takaful Elements; Academy for International Modern Studies, e-library/Islamic Banking and Finance, p. 1.
} 
- Appointment of Shariah Advisory Council or Committee to oversee the development and Islamic auditing of the Takaful operation ${ }^{32}$

The fundamental principles that distinguish Takaful from conventional insurance are ethical in content in addition to the strict requirement from adherence to the principles of Shariah. The general principles of Takaful are derived from the textual authorities of the Noble Qur'an, traditions of the Prophet pbuh and the practices of the people of Madinah.

In of the above stated fundamental requirements, one should take note that in a family Takaful contract, for example, once it is signed, the participant shall agree to relinquish as a donation (Tabarru'), a certain portion of his contribution enabling him to fulfil his obligation of mutual help and joint guarantee. The incorporation of Tabarru' (voluntary donation) is to eliminate both the element of Gharar (deceit) and Maysir (gambling). Besides enabling the participants to perform their divine duty of helping the unfortunate few in hardship, there is another aspect of the contract called Mudharabah which comprises of the profit-sharing element between the participants and the Takaful operator to enable both parties to reap some worldly benefits. This is allowable in Islam. Therefore, the Takaful contract affords the protection element as mentioned above as well as the savings or investment element. If the participant dies before maturity of the contract, the Takaful operator will compensate the heirs of the deceased; however, if the participant lived until the maturity of the contract, the benefits will be paid top him. Either way, the social obligation of helping the unfortunate few, as well as preparing for retirement days when one is physically helpless, will be met by this scheme ${ }^{33}$.

\section{Takaful under Nigerian Legal and Regulatory Framework}

Under the Nigerian legal framework, for a contract of Takaful insurance to come into existence certain essential requirements must be satisfied which are in tandem with general Common law principles of insurance contracts but devoid of the anti-Shariah features. This means the subject matter of Takaful insurance may be any movable or immovable property, and in practice is always amply described in the insurance certificate or policy. ${ }^{34}$ Furthermore, since a contract of Takaful insurance operates within the general principles of law of contract ${ }^{35}$, devoid of the anti-Shariah features, the Takaful contract may be made orally ${ }^{36}$, since there is no special form prescribed in law for making a contract of insurance. But nowadays, it is customary to embody the terms of the insurance contract in a written document because of the complexities of insurance contracts ${ }^{37}$.

All insurance contracts are not only subjected to the general principles of the law of contract in Nigeria, but also certain special legal principles that are embodied in insurance contracts. These include utmost good faith ${ }^{38}$, insurable interest, indemnity, contribution, subrogation and proximate cause.

\subsection{Takaful under the Insurance Act 2003}

The Act is the foremost legislation that regulates insurance business in Nigeria. Section 1 of the Act outlines the scope of its application in the Nigerian insurance industry and the notable omission there is the lack of express

\footnotetext{
${ }^{32}$ Fisher, O. and Taylor, D.Y., op cit, p. 14. Available at http://www.takaful.com.sa/m4sub3.asp.openaccess.htm.

${ }^{33}$ Yusuf, T.O., op cit, p. 224. See also El-Sawy, S., (2003), Financial Contracts II, The American Open University, Virginia, USA, p. 55. See also Fisher, O and Taylor, D.T., op cit, See also Redzuan, H. and Rahman, Z., and Aidid, S.S., (2009), Economic Determinants of Family Takaful Consumption: Evidence from Malaysia, International Review of Business Research Papers, 5(5), pp. 193-211.

${ }^{34}$ One may, for example insure against the theft of his property or against the property being damaged by fire. Apart from physical objects, the subject matter of Takaful insurance may consist of an event whose occurrence may expose the insured to liability against another person.

${ }^{35}$ A Takaful contract, being a simple contract, must satisfy the fundamental requirements for the making of such a contract. These include the mutuality of consent between the parties; contractual capacity, the agreement must be supported by consideration in order to ensure its enforceability; the parties must have intended to create a legally binding contract and the object of the contract must not give rise to illegality. See Okay, O., op cit, pp. 317-318.

${ }^{36}$ The only exception here under conventional insurance is that marine insurance contract must be made in writing.

${ }^{37}$ Okany, M.C., op cit, p. 813.

${ }^{38}$ The Nigerian insurance legal framework approach to the application of utmost good faith takes a slightly modified stance. In modifying the Common law principle of utmost good faith to suit the Nigerian environment, Section 54(1) of the Insurance Act 2003, shifted the burden of materiality of information from the insured or proposer to the insurer by requiring that all proposal forms should elicit such information considered by the insurer to be relevant. This is in total contrast with the provisions of standard Common law insurance practice. One can understand the reason for deviation by the Nigerian insurance legal framework, because the courts have been inundated with cases of insurance companies taking advantage of unsuspecting clients innocently seeking legal cover only to end up being short-changed by dubious insurers who always capitalize on technical loopholes to fleece unwary clients.

In Malaysia, Section 28 of the Takaful Act, 1984 codifies the requirement of utmost good faith through a strict duty to disclose, imposed on participants and operators. While this element is detailed in the Act, the origins of the requirement can be found in the common law rules that operate in Malaysia. Failure to disclose, as defined in the Act, can lead to a fine and/or imprisonment.
} 
mention of Islamic insurance or Takaful. This is a huge legal gap but the regulatory authorities are quick to point out that there is an allusion to Takaful in the provision. It maintains that the Act takes of care of Takaful insurance by inference. It is submitted that this is not good enough because Takaful is far too robust and important to be referred to by inference.

Section 86 of the Insurance Act, $2003^{39}$ vests in the National Insurance Commission of Nigeria (NAICOM) the responsibility for administration and enforcement of the provisions of the Act and authorizes it to carry out the requirements of the Act. This, in effect, places the responsibility for the regulation and enforcement of Takaful in the Commission ${ }^{40}$.

This area of administration and enforcement has been the bane of insurance practice in Nigerian and is expected to impact negatively on Takaful once it is fully entrenched if not properly checked. The vast experience of Malaysia in readily and swiftly checkmating the obstacle of enforcement in its insurance industry is instructive in this regard. Borrowing from the Malaysian success, it is paramount for character of the law to be injected into enforcement provisions if the desired effect is to be achieved in Nigeria. The insurance Act prescribes punishment for the violations of its provisions in either fines or imprisonment or both but is surprisingly silent on how the provisions should be enforced ${ }^{41}$.

It is noteworthy that in Malaysia, which is the number one Takaful practising nation in the world, insurance practice is regulated by the country's Central Bank or Bank Negara Malaysia (BNM). This makes it much easier to supervise and the provisions of the Act better enforced because insurance has now reached unprecedented level in liquidity volume and is central to ever expanding economic transformation.

\subsection{Takaful under National Insurance Commission (NAICOM) Act, 1997}

The Act establishes the Commission as a body empowered to administer, regulate, supervise and control insurance businesses and activities in Nigeria ${ }^{42}$.

The legal basis for Takaful application in Nigeria under the NAICOM Act is further enshrined in the fundamental policy objectives set for the Commission in the guidelines which include, (a) to ensure that the business of Takaful is conducted in accordance with thye Shariah and sound insurance principles, (b) to ensure that all Takaful operations are managed in an efficient and responsible manner by qualified officers of integrity, (c) to ensure that all Takaful companies are financially viable and adequately capitalized and capable of discharging their financial responsibilities, and (d) to ensure the protection of policyholders and the insuring public generally, from weak and unscrupulous insurance/Takaful practitioners who may have gone into the business with ulterior motives ${ }^{43}$.

\subsection{Takaful under the Companies and Allied Matters (CAMA) Act, 1990}

With the exception of statutory corporations such as African Insurance Corporation (Africa Re) ${ }^{44}$, all registered insurance companies are subject to the provisions of the Companies and Allied Matters Act, $1990^{45}$.

Despite the requirements for incorporation, the provisions of CAMA regulate activities of Takaful operators from incorporation to winding up just like it is with other corporate entities. The significant role played by CAMA is in the area of returns, for instance, the Takaful insurance company is required by CAMA, before it commences business, to submit to the Corporate Affairs Commission (CAC), a statement of returns in a prescribed manner,

\footnotetext{
39 "Subject to the provisions of this Act, the National Insurance Commission (in this Act referred to as "the Commission") shall be responsible for the administration and enforcement of this Act and is hereby authorized to carry out the provisions of this Act'.

40 Adamu, A.I., (2013), P. 78.

${ }^{41}$ Mr Kola Adedeji, Managing Director, Niger Insurance Plc, said in an interview that 'generally, the legislative framework for insurance practice in Nigeria is inadequate and ineffective. Often times we find the law making unenforceable provisions which though good on paper is almost impracticable without strong enforcement provisions. The law makes provisions for NAICOM to enforce the insurance laws against insurance companies through the inspectorate division in the Commission but provides no means of enforcement against the public in general The Commission has no power of arrest irrespective of the fact that there are sanctions provided in the law. How would arrest and legal action be taken to ensure sanctions are meted out to individuals in breach of the law?, he asked".

${ }^{42}$ Section 7 of the Act empowers the Commission to set standards for the conduct of insurance business in Nigeria. The Commission is also empowered to carry out regulatory activities in form of inspection, actuarial investigation and intervention with a view to ensuring control and compliance with the requirements of the law.

43 Adamu, A.I., op cit, p. 83.

${ }^{44}$ See Section 3(b) of Insurance Act, 2003.

${ }^{45}$ Section 3(a) of the Insurance Act, 2003, requires a company to be duly incorporated under the CAMA as condition precedent for registration as an insurer. Section 21 of CAMA requires an applicant for business operations to be incorporated as a limited liability company by shares or by guarantee.
} 
on the first Monday in February and on the first Tuesday in August of every year during which it carries on business ${ }^{46}$.

However, in spite of the role of CAMA in the affairs of companies, Section 100 of the Insurance Act, 2003 subjects the application of CAMA provisions or requirements to be in conformity with the requirements of the Insurance Act. The import of this requirement is demonstrated in priority order for the settlement of debts owed by insurance/Takaful operators ${ }^{47}$. Conversely, the section requires that filing of the winding up petition of the insurer/Takaful operator shall be as presented under $\mathrm{CAMA}^{48}$. It is submitted that these apparent conflicts of authority do not bode well for the smooth and effective application of insurance and Takaful insurance in particular because of its teething problems and the challenges it is facing at this point in time. Such contradictions erode the confidence and trust of the insured and the would-be insured thereby compounding the deepening penetration difficulties the insurance industry is currently grappled with. There has to be a harmonization of legislations just like what currently obtains in Malaysia and other jurisdictions. Sadly though, the Law Reform Commission of Nigeria has been virtually in perpetual slumber only stirring up occasionally to make cosmetic reforms in less critical matters. It is a thing of curiosity as to why a topical issue like this has not been a subject of proactive litigation. A declaratory pronouncement would have sufficed in putting the issue to rest.

\subsection{Takaful under the Investment and Securities Act, 2007}

The Investment and Securities Act (ISA), 2007 establishes the Securities and Exchange Commission (SEC) as the apex regulatory authority for capital market operations in Nigeria ${ }^{49}$. Although the Insurance Act, as the principal regulatory instrument of insurance business in Nigeria has not made specific mention of Investments and Securities Act (ISA), the role of ISA in the operations of key areas in the financial sector cannot be discountenanced ${ }^{50}$.

The fundamental requirement of Takaful investment operation is that it must be Shariah compliant. Therefore, Takaful investment must be tailored to suit its peculiarities and avoid the conventional interesting-paying bonds and equities. This presupposes that the assets risk profile is different from that of conventional insurance and in this regard the role of the Securities and Exchange Commission cannot be overemphasized. In pursuance of this responsibility, the Securities and Exchange Commission issued a guideline on non-interest investment portfolio in support of the peculiarities of Takaful insurance and Islamic banking in Nigeria ${ }^{51}$. However, there are inherent conflicts that abound in the provisions of the Investments and Securities Act and those of the Insurance Act concerning investment portfolio in Takaful insurance. This is discussed in greater detail in the next segment of the study.

\section{Overcoming the Regulatory Challenges in Takaful Application}

As laudable as the objectives of Takaful are, what remains critical to the realization of these financial inclusion objectives is overcoming the plethora of challenges that confront this trending form of insurance often referred to as "insurance with a human face". There are general, specific and regulatory challenges that abound which, if not handled properly and in time, will surely act to the detriment of the teeming populace who have waited patiently and for so long for this financial inclusion opportunity.

Part of the problems identified by the NAICOM diagnostic study ${ }^{52}$ on insurance which is in tandem with the objects of this study, is that the current regulatory framework of insurance in Nigeria is not adequate for the development of micro insurance and Takaful by extension to full potential. The study found that the current rules include high entry requirement and operating minimum standard and excessive reporting which were not

\footnotetext{
${ }^{46}$ Section 553 of Companies and Allied Matters Act, 1990.

47 Section 32(4) Insurance Act, 2003.

${ }^{48}$ Section 32(1)(a) and (2) of the Insurance Act, 2003.

49 The Act provides regulatory framework for capital market, protection of investors, maintaining fair, efficient and transparent market and prevention of systemic risks and other related matters.

${ }^{50}$ Section 13(a) and (p) of the Investments and Securities Act empowers the Securities and Exchange Commission, among other things, to do the following:-

(i) regulate investments and securities business in Nigeria;

(ii) review, approve and regulate mergers, acquisitions, takeovers and all forms of business combinations and affected transactions of all companies.

${ }^{51}$ Adamu, A.I., op cit, p. 87.

${ }^{52}$ NAICOM/Access to Insurance Initiative Report, Towards Inclusive Insurance in Nigeria, Eschborn 2013, p. 27
} 
developed to meet the peculiarities of Takaful operations.

This study posits that considering the challenges and opportunities posed by regulation of the insurance industry and the specific business needs of Takaful operations in Nigeria, there will be need to draw heavily from the Malaysian experience in overcoming these teething challenges. There is a greater need for a more enabling regulatory framework just like the Malaysian Takaful Act of 1984 in addition to a strict minimum consumer protection and market conduct standards that are effectively enforced. This will no doubt serve to protect the Takaful operators while at the same time protecting the policyholders.

\subsection{Absence of Express Legislative Mention of Takaful}

The most critical regulatory challenges currently facing the nascent Takaful industry in Nigeria have to do with so many provisions of the Insurance Act, 2003 that appear to be in conflict with the released Takaful Guidelines of 2013. Specifically, Section 1 of the Insurance Act makes no mention of Islamic insurance or Takaful at all. A careful perusal of the provision shows an express omission of the term Takaful or Islamic insurance. This absence of legislative mention is a grave error that is bound to produce ambiguities in the complex application of Takaful under conventional insurance in Nigeria. Takaful is quite different from conventional insurance and as such should have been specifically provided for in the Insurance Act. The resultant ambiguity is bound to make potential investors and clients consider the situation too risky to invest their hard earned capital into high level of uncertainties. Furthermore, Takaful operators might be reluctant to invest more on marketing and product development since there are no express legal guarantees to protect them due to conflict of laws. Explicit regulatory and supervisory guidelines have the propensity to clear several foggy areas for all stakeholders.

The effectiveness and efficiency of the Takaful Operational Guidelines which are already in conflict with the basic provisions of the Insurance Act are being questioned two years after their introduction and have contributed to the slow start of full-fledged Takaful operations in Nigeria. This view corroborates that of Saad, Gambo and Kassim who posit that potential investors will question the murky nature of the Nigerian insurance legislation $^{53}$ towards the application of Takaful.

\subsection{Regulatory Conflicts}

Still on the conflicting provisions in the two foremost insurance regulating instruments, Section 9 of the Insurance Act which provides for minimum paid up capital was relaxed in the Takaful Guidelines to scale down the minimum paid up capital for Takaful insurers to N100 million ${ }^{54}$ about MYR2 million. This accommodation for Takaful is however, subject to controversy as the National Insurance Commission's power under the Act relates only to upward review of the minimum paid-up share capital and not its downward review ${ }^{55}$. It remains arguable whether the power to increase paid-up share capital vested in the Commission would accommodate the discretion to decrease in the prescribed minimum paid-up capital.

Another potential area of conflict which poses a huge challenge to the application of Takaful in Nigeria is found in Section 10 of the Insurance Act. The section requires an insurer/Takaful operator intending to commence business, to deposit the equivalent of fifty per cent of the paid-up share capital with the Central Bank of Nigeria (CBN) as its statutory deposit. However, after registration, eighty per cent of the statutory deposit would be released to the insurer/Takaful operator with interest not later than sixty days after registration. The section further states that in the case of an existing company, ten per cent of the paid-up share capital shall be deposited with the $\mathrm{CBN}$ attracting interest at $\mathrm{CBN}$ rate on the $1^{\text {st }}$ of January each year.

The issue of interest (Riba) is what is unacceptable to the Takaful operator because it clearly violates Shariah principles. Riba is often translated as 'usury' or 'interest' for which no counter value is given. It is often regarded as any unjust or excessive gain or unjustified increase in capital for the earning of which no appropriate effort was made ${ }^{56}$.

Yet again, the investment portfolio provision contained in Section 25 of the Insurance Act is a potential source of conflict with the Takaful Operational Guidelines, 2013. The basic requirements for investment in Takaful are its compliance with Shariah principles. This presupposes that the investment must be devoid of the Shariah prohibitive elements namely, interest, uncertainty and gambling. The Takaful Operational Guidelines impress on

\footnotetext{
${ }^{53}$ Gambo, G., Sa'ad, N. \& Kassim, S., (2014) 'Assessing the Impact of Islamic Micro-Finance on Poverty Alleviation in Northern Nigeria. Journal of Islamic Economics, Banking and Finance, Vol. 10, No. 4, October-December, 2014. Available at http://ibtra.com/journal_current_issue.php.

${ }^{54}$ Paid-up share capital requirement contained in the registration requirements for Takaful operation.

${ }_{55}$ See Section 9(4) Insurance Act, 2003.

${ }^{56}$ Mannan, M.A., (1980) Islamic Economic Theory and Practice, Delhi, p. 161.
} 
the operator to establish investment policies for the Participants' Risk Fund (PRF) and Participants' Investment Fund $(\mathrm{PIF})^{57}$. However, Section 25 of the Insurance Act, which is the main regulatory law, provides for investment by an insurer in a totally different way from the provisions of the Takaful Guidelines. There is no express exemption of Takaful from the requirements of Section 25 of the Insurance Act. Furthermore, interest is a key component of admissible assets under Section 24(13) of the Insurance Act, while under Takaful it is an averting factor of the transaction. This view, however, depends on the purification concept stipulated in Section 4.4(a) of the Takaful Operational Guidelines.

What remains unclear is whether Section 25 of the Insurance Act will apply to Takaful insurance. If the provisions of the Act do apply besides the regulations of Takaful investment in the Guidelines, the Takaful operator must also meet the requirements of Section 25 of the law. The supremacy of the Insurance Act in regulating insurance business in Nigeria has been clearly stated in Section 100 of the Act ${ }^{58}$. The murky nature of this plethora of regulatory challenges facing Takaful insurance will not bode well for its smooth application in Nigeria.

The Malaysian experience is critical here in solving the regulatory conflicts that plague the Nigerian Takaful industry. A comprehensive Takaful Act like the Malaysian Takaful Act will no doubt solve the vexing issue of lack of legislative mention of Takaful insurance in the Insurance Act 2003. There has to be a clear delineation of authority between the Takaful Guidelines and the Insurance Act. In Malaysia, although the Central Bank of Malaysia (BNM) is responsible for administering both Takaful and conventional insurance, the operation of both industries is mutually exclusive. Section 67(1) of the Malaysian Takaful Act 1984 expressly states the supremacy of the Takaful Act to any other legislation pertaining to Takaful insurance ${ }^{59}$. The Nigerian Takaful industry is in dire need of a comprehensive Takaful Act to safeguard the nascent Takaful environment.

The Malaysian Takaful Act, through various measures, incentivizes the development of Takaful. The specific incentives provided to Takaful operators in the Takaful Act make Islamic insurance an economically attractive financial product for insurance companies to offer. On a macro level, Malaysia has introduced a few key regulations in order to encourage the growth of the Takaful industry. Incentives are necessary to enable Takaful operators to competitively price their products when compared to conventional insurers that operate side by side. The first incentive offered to Takaful operators is tax incentive and neutrality ${ }^{60}$.

\subsection{Conflict of Laws}

As Nigeria is still governed by civil law, there are times conflict of laws arises with regard to their interpretations. Takaful contracts are expected to comply with Shariah rules and principles, as well as with the laws of the civil jurisdiction in which contracts are to be enforced. This is a potential are of friction because of the fundamental differences between Islamic and conventional laws. Insurance is a contract that is governed by the Received Common law of contract as well as the Insurance Act and other statutory enactments, whereas Takaful is primarily governed by Shariah law and the recently released Takaful Guidelines. The issue of jurisdiction is critical here as the released Guidelines have been silent on the exclusivity of Shariah law application on Takaful contrary to what obtains in other operating countries ${ }^{61}$. The Malaysian experience in dealing with such an issue

\footnotetext{
${ }^{57}$ The requisite policies shall include: The Takaful operator must seek to manage funds aligned with Shariah compliant methodology as practiced internationally and approved by its Advisory Committee of Experts (ACE)

${ }^{58}$ Section 100 of the Insurance Act, 2003, provides:

"The provisions of this Act are without prejudice to the application of the Companies and Allied Matters Act, 1990 and any other enactment applicable to insurance under this Act which are companies registered under that Act, so however, that where any of the provisions of the Companies and Allied Matters Act, 1990 and other enactment is inconsistent with any provision of this Act, the provision of this Act shall prevail to the extent of that inconsistency.

${ }^{59}$ Where there is any conflict or inconsistency between the provisions of this Act and those of the Companies Act 1965, the Contracts Act, 1950, the Insurance Act, 1996, the Road Traffic Ordinance 1958 and the Co-operative Societies Act, the provisions of this Act shall prevail.

Section 67 (2) further provides that Without prejudice to the generality of subsection (1), for the avoidance of doubt, it is hereby declared that the provisions of the Insurance Act 1963 shall not apply in relation to a company or society under this Act and carrying on any business which is insurance business within the meaning of same under the Insurance Act, 1963, and the provisions of all written laws shall apply to such company or society authorized by law to carry on such business and issue any policy or certificate required under any written law in relation to such business.

${ }^{60}$ Section 2(8) of the Income Tax Act, 1967, allows Shariah compliant institutions, including Takaful operators, to apply for tax neutrality or incentives. Any financing scheme necessary to ensure Shariah compliance would be eligible under his section to apply for tax neutrality. In essence this offers Takaful companies a level playing field with their conventional counterparts.

${ }^{61}$ In Malaysia, for example, in the event where there is a dispute before the court or arbitrator which involves the Takaful business in relation to any Shariah matters, the court or arbitrator is required to make reference to the Shariah Advisory Council (SAC) of the Central
} 
cited in the footnote is instructive here.

\subsection{Breaches by a Takaful agent}

A Takaful agent, as an intermediary, is a legal agent of a Takaful operator (as the principal). Agents are authorized to act as the marketing channel of Takaful products on behalf of a Takaful operator. However, agents and principals are also bound by common law rules governing agency relationships. It is trite agency rule that a principal will not be held liable for any dealings or transactions carried out by an agent beyond his or her authorized express power, implied power or common authority power ${ }^{62}$. Therefore, there is bound to be complication for the participants when they claim for their rights on any misconduct of the Takaful agents. If proven that the agents have acted beyond their powers, the Takaful operator, as principal, may deny liability. At the end of the day, the participants/public are the parties at $\operatorname{loss}^{63}$. This is another potential area of friction in the laws that is bound to cause problems in the relationship between the Takaful operator and participants that hugely depends on trust and transparency.

In Malaysia, a Takaful agent is licensed under the Takaful Act, 1984. Section 181 of the Contracts Act 1950 exempts a principal from the liability of an agent where he exceeds his authority. This is a general problem for Takaful participants in stating their claims. The greater loss will be that of the industry if trust is eroded between the parties. Malaysia itself is yet to deal with this conflict decisively.

\subsection{Shariah Framework}

The Nigerian Takaful regulators will need to borrow a leaf from the Malaysian Shariah framework that has fortified and insulated Takaful insurance from unnecessary legal entanglement on the question of jurisdiction. The Bank Negara Malaysia (BNM) or the Malaysian Central Bank has established the Shariah Advisory Council (SAC) under the Bank Negara Malaysia Act, 1958. The SAC, via amendment to the Act, was accorded sole authority on Shariah matters pertaining to Islamic banking and Takaful business ${ }^{64}$. It is responsible in ensuring Takaful operations are in compliance with Shariah parameters. Section 53(a)(1) of the Takaful Act, 1984 provides that any parties involved in a Takaful transaction, namely a Takaful operator, a Takaful agent, a Takaful broker or an adjuster, may seek the advice of the Shariah Advisory Council in matters relating to its or his Takaful business ${ }^{65}$. In the event where there is a dispute before the court or arbitrator which involves the Takaful business in relation to any Shariah matters, the court or arbitrator is required to make reference to the SAC of the Central Bank of Malaysia by virtue of Part VII of CBMA 2009. Once the reference is made to SAC their decision is binding on the courts and the arbitrator ${ }^{66}$. Some academics have been critical of this wide ranging power that is granted a body which is not a court of competent jurisdiction as enshrined in the Malaysian constitution $^{67}$.

\subsection{Nigerian Takaful Association}

Nigerian Takaful operators will need to come together and establish a vibrant Takaful Association to help co-ordinate their activities and protect their interests and those of their teeming clients. In Malaysia, Takaful operators have established an industry association known as Malaysian Takaful Association (MTA) in 2002, under Malaysian Societies Act of 1966. As a requirement for carrying on business, a Takaful operator must become a member of MTA as provided in Section 4(2) (b) of the Takaful Act. The MTA aims to improve industry self-regulation through uniformity in market practices and promoting a higher level of cooperation among the players in developing the Takaful industry ${ }^{68}$. A Road Map Strategy lays out the direction and focus of

\footnotetext{
Bank of Malaysia (BNM) by virtue of Part VII of the Central Bank of Malaysia Act, 2009. Once the reference is made to SAC, their decision is binding on the courts and arbitrator.

See also Section 56 of the Central Bank of Malaysia Act 2009.

Section 63 of the Malaysian Takaful Act 1984 provides that any prosecution in respect of any offence under the Act is to be referred to the Magistrate Court. There are also other laws applicable to Takaful matters, in which Section 67 of the Takaful Act 1984 allows the application of the Companies Act, Contracts Act, 1950 and Insurance Act, 1996, Road Traffic Ordinance, 1958 and Co-operatives Societies Act. In the event where there is a conflict or inconsistency between the Takaful Act and other Acts, the Takaful Act prevails. This should be compared with Section 100 of the Nigerian Insurance Act 2003 cited previously which claims supremacy in any matter on insurance in Nigeria.

${ }^{62}$ Ahmad, R. \& Auzzir, Z.A., op cit p. 39.

${ }^{63}$ Ibid.

${ }^{64}$ Takaful Annual Report, 2003, Bank Negara Malaysia.

${ }^{65}$ Rahman, Z.A. \& Redzuan, H., (2009), Takaful: The $21^{\text {st }}$ Century Insurance Innovation, McGraw-Hill, Sdn Bhd, Malaysia, p. 114.

${ }^{66}$ Section 56 of the Central Bank of Malaysia Act, 2009.

${ }^{67}$ Prof. Dato Ahmed Hidayat Buang of the Islamic Academy, Universiti Malaya, has been critical of the powers of the SAC.

${ }^{68}$ Takaful Annual Report, 2004, Bank Negara Malaysia
} 
the association, with the objective of achieving a substantial share in the Malaysian insurance industry ${ }^{69}$. The focus among others, is on branding, awareness and communication, shared services through leveraging of technology, investment opportunities and relations with regulators ${ }^{70}$. Another very important function of MTA is the implementation of Inter-Takaful Operator Agreement (ITA) among its members, which sets a common standard among all operators to regulate on and control matters pertaining to pre-contract examination for agents, agency registration system and code of ethics, and compliance with the general Takaful tariff for motor and fire lines $^{71}$. The implementation of ITA is essential to streamline market practices among Takaful operators and to harmonize the Takaful and conventional insurance industry ${ }^{72}$.

\subsection{Takaful Guarantee Fund Scheme}

The most important reason for insurance regulation is promoting insurer solvency. Insurance solvency is the financial ability of the insurer to pay claims when they become due. The Nigerian insurance industry is badly in need of this assurance because of the pervading cynicism about insurance as a result of non-settlement of claims by insurers even where such claims have been certified valid. Takaful must not fall into this quagmire if it is to make any meaningful impact in the Nigerian insurance terrain.

Investors' Dictionary defines solvency margin as the minimum standard of financial health for an insurance company, when assets exceed liabilities. Insurance regulations are designed to protect the public interest by ensuring a financially sound insurance industry. The aim of insurance regulation for solvency is to establish a proper system for efficient and safe operation, and to minimize possible insurer failures ${ }^{73}$. This involves early detection of financial difficulties faced by an insurer, prompting corrective measures and minimizing the impact of the financial problem that occurred. The impact of dealing with insolvent insurer could be very distressing to the insurance buyers. Claims might be denied at the time when financial assistance is most sought after, for example after the death of the main bread-winner, or after a home is totally destroyed by fire. Solvency of an insurer is thus very important in any insurance transaction ${ }^{74}$.

In insurance or Takaful, premium is paid in advance and the period of protection extends into the future. The promise of an insurer to pay claim may be due soon after the contract is in force, or may be much later. If an insurer is insolvent, then it would not be able to fulfil its obligation to meet claims. Solvency makes the results of insurance transaction certain and predictable ${ }^{75}$. It builds trust and confidence. This is the function of insurance; to reduce financial risk and uncertainty faced by individuals in the event of a loss occurring ${ }^{76}$.

To reduce the risk of a Takaful operator experiencing insolvency, the Malaysian Takaful Act empowers the Director-General to establish and maintain a separate Takaful Guarantee Scheme Fund (TGSF) for general business and family business ${ }^{77}$. The main function of TSGF is for meeting the liabilities of nay insolent operator. It is funded mainly from levies imposed on licensed operators. Other sources of funds into the TSGF include profit or dividend from investment.

This is a noble scheme worthy of emulation by the Nigerian Takaful regulator, the National Insurance Commission of Nigeria (NAICOM).

\section{Conclusion}

This study discussed the introduction of Takaful Operational Guidelines, 2013 by the National Insurance Commission of Nigeria (NAICOM) and the regulatory challenges it is facing in the application of Takaful under conventional insurance. An overview of the Nigerian insurance landscape preceded the discussion on the fundamentals of Takaful insurance. The discussion on the regulatory framework of Takaful in Nigeria was instrumental in elucidating the level of regulatory conflicts that abound in the insurance industry and how if not overcome will stifle the growth of Takaful.

The study carefully examined the experience of Malaysia in dealing with such regulatory conflicts and found

\footnotetext{
${ }^{69}$ Rahman, Z.A. \& Redzuan, H., op cit, P. 115.

${ }^{70}$ Malaysian Takaful Association, 2008, MTA's role and functions, MIF Monthly Takaful Supplement.

${ }^{71}$ Rahman, Z.A., \& Redzuan, H., op cit, p 115.

72 Rahman, Z.A. \& Redzuan, H., op cit, p. 115.

${ }^{73}$ Redja, G., (2003), Principles of Risk Management and Insurance, $8^{\text {th }}$ Edition, Addison Wesley, USA, p. 87.

${ }^{74}$ Ibid,

${ }^{75}$ Dorfman, G., (2001), Introduction to Risk Management and Insurance, $7^{\text {th }}$ Edition, Prentice Hall, USA, p. 98.

${ }^{76}$ Ibid.

77 Section 21 of the Act.
} 
that there is a need for a comprehensive Takaful Act in the mould of the Malaysian Takaful Act, 1984 in order to harmonize the regulatory discrepancies in the Insurance Act, 2003, Takaful Operational Guidelines, 2013 and a host of other enabling regulatory instruments. In the interim, the study recommends the immediate harmonization of all insurance instruments through an amendment of the Insurance Act, 2003 as they relate to Takaful and the statutory underpinning of a Nigerian Takaful Act as a permanent solution.

\section{References}

Achike, O. (1985). Commercial Law in Nigeria. University Press.

Adamu, A. I. (2013). Challenges of Integrating Takaful (Islamic Insurance) Within Legal and Regulatory Framework of Insurance in Nigeria (Unpublished LL.M Thesis).

Adekoya, A. I. B. (2012). Will Takaful Make a Difference? Dateline Insurance Magazine, 1(5).

Ahmad Nordin, M. T. (2007). Understanding Takaful and the Challenges Ahead. General and Takaful Agents Convention.

Ahmad, H. (2000) Evolution of Islamic Banking and Insurance as a System Rooted in Ethics. New York: Takaful Forum, April, 26.

Ahmad, S. Y. (2009). Takaful: Potential Demand and Growth. Malaysia, Faculty of Business Management, University of Malaya.

Ahmed, A. B. (2010). Techniques of Writing a Research Proposal in Law. In Ahmed A. B. (Ed.), Issues in Research Methodology in Law. Ahmadu Bello University Press, Zaria.

Ahmed, S. (2006). Islamic Banking, Finance and Insurance. A. S. Noordeen Publishers, Kuala Lumpur.

Ahmed, S. (2006). Islamic Banking, Finance and Insurance: A Global Overview, A.S. Noordeen Publishers, Kuala Lumpur.

Aiman, F. Y. (2009). Takaful Effective Marketing and Sales Practices IBFIM. Parcetakan Mesbah Sdn Bhd $(819193-\mathrm{K})$.

Al Tirmidhi and Ibn Majah.

Alabadan, S. (2012). NAICOM with Guidelines for Islamic Insurance. Daily Independent Newspaper site, $24^{\text {th }}$ August.

Al-Ajmi, J., Hussain, H. A., \& Al-Saleh, N. (2009). Clients of Conventional and Islamic Banks in Bahrain: How They Choose Which Bank To Patronize. International Journal of Social Economics, 36(11), 1086-1112. http://dx.doi.org/10.1108/03068290910992642

Ali, K. (2004). Islamic Insurance: A Modern Approach to Islamic Banking. London: Routledge Curzon, Taylor and Francis Group.

Ali, K. M. M. (1989). Need for Islamic Insurance. Islamic Banking and Insurance Proceedings and Papers of International Seminar held in Dhakar

Allen, F.T. (1936). General Principles of Insurance. New York.

Al-Qardawi, Y. (2001). The Lawful and Prohibited in Islam, Islamic Book Trust.

Anderson, J. N. D. (1959). Islamic Law in the Modern World. London.

Arbouna, M. B. (2008). Regulation of Takaful Business: A Shariah Overview of Contractual Aspects of Takaful Models, in Essential Readings in Islamic Finance. CERT Sdn Bhd.

Arbouna, M. B. (2008). Regulation of Takaful Business; A Shariah Overview of Contractual Aspects of Takaful Models; Essential Readings in Islamic Finance (Bakar, M.D. \& Ali, E.R.A.E. (eds)) CERT Publications Sdn Bhd, Kuala Lumpur.

Archer, S., \& Abdel Karim, R. (2009). Conceptual, Legal and Institutional Issues Confronting Takaful. Takaful Islamic Insurance. http://dx.doi.org/10.1002/9781118390528

Bakar, M. D., \& Ali, E. R. A. (Eds.). (2008). Essential Readings in Islamic Finance. Kuala Lumpur, CERT Publications Sdn Bhd.

Barou, H. (1936). Cooperative Insurance. London.

Bentham, J. (1931). The Theory of Legislation. London. 
Billah, M. (2003). Islamic and Modern Insurance Principles and Practices. Kuala Lumpur, Malaysia, Ilmiah Publishers.

Billah, M. (2005). A study in Islamic Insurance. Journal of Islamic Banking and Finance, 3(3), 49-66.

Billah, M. M. (2006). Shariah Standard of Business Contract, A.S. Noordeen Publishers, Kuala Lumpur.

Billah, M. M. (2006). Shariah Standard of Business Contract. A.S. Noordeen Publishers, Kuala Lumpur.

Billah, M. M. (n.d.). General Takaful Business. Retrieved from www.kantakji.com/fiqh/Files/Insurance/147.doc

Bukar, B. A., \& Saleh, M. M. (2013). Integrating Islamic Insurance Within The Framework Of Conventional Insurance In Nigeria. Journal of Arts and Sciences.

Chai, P. C. (2005). Principles of Insurance Law. Lexis Nexis, Utopia Press Pte Ltd.

Chai, P. C. (2009). General Insurance Law. Utopia Press Pte Ltd.

Cheshire, G. C., \& Fifoot, C. H. S. (1964). The Law of Contract. London.

Chua, A. O. (2000). A Critical Evaluation of Insurance and Takaful. Proceedings from The International Conference On Takaful/Islamic Insurance, Kuala Lumpur.

Coulson, N. J. (1964). A History of Islamic Law. Edinburgh.

Daniel, F. (2012). Challenges, Prospects of Takaful Insurance, This Day Newspaper Article. Retrieved August 6, 2015 from http://www.thisdaylive.com/articleschallenges-prospects-of-takaful-insurance/118793/

Divanna, J., \& Shreih, A. (2009). A New Financial Dawn: The Rise of Islamic Finance. United Kingdom, Leonardo and Francis Press Ltd.

Dorfman, M., (2001). Introduction to Risk Management and Insurance (7th ed.). Prentice Hall, USA.

Ezamshah, I. (2011). Basic Takaful Broking Handbook. IBFIM, Kuala Lumpur.

Fadun, O. S. (2014). Takaful (Islamic Insurance) Practices: Challenges and Prospects in Nigeria. Journal of Insurance Law \& Practice, 4(2).

Fadzli, M. et al. (2011). Fundamentals of Takaful. Kuala Lumpur Publishers.

Ferguson, T. (2008). "Takaful 2.0" Using the Power of the Web to Realise the Global Holy Qur'an: Text, Translation and Commentary By Abdullah Yusuf Ali, Sartaj Company.

Fisher, O., \& Taylor, D. Y. (2000). Prospects for Evolution of Takaful in the $21^{\text {st }}$ Century. Havard University, USA.

Fisher, O., \& Taylor, D. Y. (2000). Prospects for the Evolution of Takaful in the $21^{\text {st }}$ Century. Retrieved from http://www.takaful.comsa/m4sub3.asp.openaccess.htm

Fitzgerald, S. G. V. (1955). Nature and Sources of the Shariah. In Law in the Middle East. Frenz, T., \& Soualhi, Y. (2010). Takaful and Retakaful IBFIM. Munich Re Percetakan Mesbah Sdn. Bhd.

Friedman, W. (1953). Legal Theory. London.

Funmi, A. (1992). Nigerian Insurance Law. Dalson Publications Limited.

Funmi, A. (2007). Nigerian Insurance Law (2nd ed.).

Gambo, G., Saad, N., \& Kassim, S. (2014). Assessing the Impact of Islamic Micro-Finance on Poverty Alleviation in Northern Nigeria. Journal of Islamic Economics, Banking and Finance, 10(4). Retrieved from http://ibtra.com/journal_current_issue.php

Haiss, P., \& Sumegi, K. (1999). The Relationship of Insurance and Economic Growth - A Theoretical and Empirical Analysis.

Holy Qur'an, Al- Nisa' Chapter 4 Verse 29.

Hurgronje, Selected Works (eds. Bousquet and Schacht). (1957). Lieden.

IFSB-IAIS. (2006). Issues in Regulation and Supervision of Takaful.

International Business Research. (2013, February 13). Retrieved from www.ccsenet.org/ibr

International Cooperative and Mutual Insurance Federation (ICMIF) Takaful. (2013). Retrieved from www.Takaful.coop/index.php

Irukwu, J. O. (1991). Insurance Law and Practice in Nigeria. Heinemann, Ibadan. 
Irukwu, J. O. (1993). Fundamental Principles of Insurance Law.

Ismail, A. (2002). Islamic Risk, Asset Management and Wealth Distribution. Lecture Series for Persatuan Remisier Bumiputra, Malaysia.

Jching, Y. B. (2008). MARC's Approach to Rating Institutions Offering Takaful. MIF Monthly, Takaful Supplement.

Kassim, Z. A. M. (2005). Takaful: The Islamic Way of Insurance. Contingencies (January-February): 33.

Kazi, M. D., \& Mortuza, A. (2011). Present Scenario and Future Potentials of Takaful.

Kettle, B. (2008). Introduction to Islamic Banking and Finance. London: Brian Kettle Islamic Banking Training.

Khadduri, M. (1960). War and Peace in the Law of Islam. Baltimore.

Khorshid, A. (2004). Islamic Insurance: A Modern Approach to Islamic Banking. Routledge Curzon, London. http://dx.doi.org/10.4324/9780203458280

Khurshid Ahmad in Muslehuddin, M. (2012). Insurance and Islamic Law. Adam Publishers and Distributors, New Delhi.

Kollere, A. U. (2014). Takaful Insurance: Towards Deepening Insurance Penetration. Daily Trust Newspaper, p. 38.

Ma'sum, B. M. (2001). Principles and Practices of Takaful and Insurance Compared. Malaysia, International Islamic University of Malaysia.

Ma'sum, B. M. (2001). Takaful (Islamic Insurance): An Economic Paradigm. International Cooperative and Mutual Insurance Federation (Icmif).

Mahmood, N. R. (1991). Takaful: The Islamic System of Mutual Insurance-The Malaysian Experience. Arab Law Quarterly, 6(3). http://dx.doi.org/10.2307/3381379

Mahmoud, H. (2008). Insurance; Takaful Gaining Ground. The Actuary.

Manjoo. (2007). Islam and Financial Intermediation. Documented Papers in Malaysia, March 29, (1).

Mannan, M. A. (1980). Islamic Economic Theory and Practice. Delhi.

Maysami \& Kwon. (1999). An Analysis of Islamic Takaful Insurance. Journal of Insurance Regulation.

Maysami, R. C., \& Kwon, W. J. (1999). An Analysis of Islamic Takaful Insurance, A Cooperative Insurance Mechanism. Journal of Insurance Regulation, 26, 109-132.

McConnell, C. R. (1984). Economics: Principles, Problems and Policies. McGraw-Hill Book Company, US.

Mher, M. H., \& Ahmad, T. P. (2011). Conceptual and Operational Difference, General Takaful and Conventional Insurance. Australian Journal of Business and Management Research, 1(8), 23-28.

Mohammed, T. U. (2003). The Text Of The Historic Judgement On Riba By Supreme Court Pakistan. Islamic Book.

Mohd Kassim, Z. A. (2005). The Islamic Way of Insurance Contingencies.

Morgan, T. W. (Ed.). (1933). Porter's Laws of Insurance. London.

Muslehuddin, M. (2012). Insurance and Islamic Law. Adam Publishers and Distributors, New Delhi.

Nasser Y. (2011). Takaful: Study Guide. Kuala Lumpur Publishers.

Nasser, Y., \& Jamil, R. (2011). Takaful: A Study Guide. IBFIM, Kuala Lumpur.

Nik, R. M. (1991). Takaful: The Islamic System of Mutual Insurance-The Malaysian Experience. Arab Law Quarterly.

Obaidullah, M. (2005). Islamic Financial Services. Retrieved from http://www.islamic-finance.net

Obilade, A. O. (2007). The Nigerian Legal System. Spectrum Books Limited, Ibadan, Nigeria.

Okany, M. C. (1992). Nigerian Commercial Law. Africana First Publishers Plc.

Okay, A. (1985). Commercial Law in Nigeria.

Olusegun, Y. (1992). Insurance Law in Nigeria (3rd ed). Nigeria Revenue Projects Publisher, Lagos.

Owoeye, J. E. (2011). Information Communications Technology (ICT): Used as a Predictor of Lawyers Productivity. 
Paton, G. W. (1951). Jurisprudence. Oxford.

Rahim, A. (1963). Muhammadan Jurisprudence. Beirut.

Rahman, I. (1979). Islamic Interest-free Banking. IMF Staff Papers, March 27, 1979.

Rashid, S. K. (1993). Islamization of Insurance- A Religio-Legal Experiment in Malaysia. Religious and Law Review, 2(1).

Rodziah, A., \& Zairol, A. A. (2013). Takaful, Pearson Malaysia Sdn Bhd.

Rosly, S. A. (1997). Economic Principles in Islam International Islamic University Malaysia (IIUM). Journal of Economics and Management, 5.

Rosly, S. A. (1997). Economic Principles in Islam, International Islamic University of Malaysia (IIUM). Journal of Economics and Management.

Rosly, S. A. (2005). Critical Issues on: Islamic Banking and Financial Markets, Islamic Economics, Banking and Finance, Investment, Takaful and Financial Planning. Dinamag Publishing, 600000, Kuala Lumpur, Malaysia.

Rusni, H. (2011). Islamic Banking and Takaful. Pearson Malaysia Sdn Bhd.

Rusni, H., (2011). Islamic Banking and Takaful. Pearson Custom Publishing.

Schacht, J. (1953). An Introduction to Islamic Law. Oxford.

Shafi'i, Z., \& Zakaria, N. (2013) Adoption of International Financial Reporting Standards and International Accounting Standards in Islamic Financial Institutions From the Practitioner's Viewpoint. Middle East Journal of Scientific Research.

Shankar, S. (2008). Conventional Insurers Slow to Capitalize on Takaful Potentials. MIF Monthly, Takaful Supplement.

Sheikh Bin Baz. (1999, May 20). The Economist. Retrieved from www.theeconomist.com

Siddiqi, M. N. (1985). Insurance in an Islamic Economy. United Kingdom: The Islamic Foundation.

Stagg-Macey, C. (2007). An Overview of Islamic Insurance, No. 8.

Sudin, H., \& Wan Nursofiza, W. A. (2009). Islamic Finance and Banking System: Philosophies, Principles and Practices. McGraw - Hill, Malaysia Sdn. Bhd.

Sudon, H., \& Wan Nursofiza, W. A. (2009). Islamic Finance and Banking System: philosophies, Principles and Practices. McGraw Hill-Publishers (Malaysia) Sdn. Bhd.

Suzanne, W. (2013). Islamic Insurance Markets and The Structure of Takaful. Retrieved from www.qfinance.com/

Syed, A. M. S. (2008). Islamic Banking: Trend, Development and Challenges, In Essential Readings in Islamic Finance.

Taiwo, A. (2011). Basic Concepts in Legal Research Methodology, A Practical Guide on Writing Excellent Master and Doctoral Thesis. (St. Paul's Publishing House Ibadan).

Takaful Malaysia. (2007). Retrieved May 9, 2013, from www.Takaful-malaysia.com

Taylor. (2000). Some Theoretical Aspects of an Islamic Takaful System, Paper presented at a Conference on Islamic Banking, Sponsored by the Central of the Islamic Republic of Iran, Tehran.

Tobias, F., \& Younes, S. (2010). Takaful \& Retakaful, IBFIM, Kuala Lumpur.

Venardos, A. M. (2005). Islamic Banking and Finance in South-East Asia its Development and Future. B \& Jo Enterprise Pte ltd.

Venardos, A. M. (2005). Islamic Banking and Finance: Its Development and Future, Singapore, World Scientific Publishing. http://dx.doi.org/10.1142/5751

Yusof, M. F. (1996). Takaful Sistem Insurans Islam, Kuala Lumpur, Utusan Publications and Distributors. Also see Rashid, S.K., (2005), A Religio-Legal Experiment in Malaysia. Religion and Law Review, 2(1).

Yusuf, T. O. (2012). Prospects of Takaful's (Islamic insurance) Contributions to the Nigerian Economy. Journal of Finance and Investment Analysis, 1(3). 
Yusuf, T. O. (2012). Prospects of Takaful's (Islamic insurance) Contributions to the Nigerian Economy. Journal of Finance and Investment Analysis, 1(3), 217-230.

Yusuf, T. O., \& Babalola, A. R. (2015). Takaful in Nigeria: Penetration Challenges and Way Forward.

Zulkifli, A. et al. (2012). Basic Takaful Practices Publication of IBFIM \& Malaysian Takaful Association.

Zuriah, A., \& Hendon, R. (2009). Takaful: The $21^{\text {st }}$ Century Insurance Innovation. McGraw - Hill (Malaysia) Sdn Bhd.

Zuriah, A., \& Hendon, R. (2009). Takaful: The $21^{\text {st }}$ Century Insurance Innovation. McGraw-Hill (Malaysia) Sdn Bhd.

\section{Copyrights}

Copyright for this article is retained by the author(s), with first publication rights granted to the journal.

This is an open-access article distributed under the terms and conditions of the Creative Commons Attribution license (http://creativecommons.org/licenses/by/4.0/). 